\title{
Long Voyage: African Migration through Latin America to the US
}

\author{
Fikresus (Fikrejesus) Amahazion \\ College of Arts and Social Sciences, Adi Keih, Eritrea \\ Email: fikrejesus87@gmail.com
}

How to cite this paper: Amahazion, F. (2021). Long Voyage: African Migration through Latin America to the US. Open Journal of Social Sciences, 9, 280-300. https://doi.org/10.4236/jss.2021.97020

Received: June 16, 2021

Accepted: July 18, 2021

Published: July 21, 2021

Copyright (c) 2021 by author(s) and Scientific Research Publishing Inc. This work is licensed under the Creative Commons Attribution International License (CC BY 4.0).

http://creativecommons.org/licenses/by/4.0/

\begin{abstract}
Throughout the history of humankind, people have migrated from one location to another. For many decades, one of the most heavily traveled migratory routes in the world has been the one from Latin America north toward the United States (US). Millions of people from Mexico, the Northern Triangle region of Central America, and other parts of Latin America have traveled north in search of economic opportunity, to reunify with family members, to seek refuge from violence, insecurity, and persecution, or for various other reasons. However, in recent times, particularly during the last decade, the demographic profile of migrants moving through Latin America toward the US has significantly changed and diversified. A growing number of migrants originating from countries in Africa have traveled to Latin America seeking to transit northward to the US. Despite the recent growing number of arrivals in Latin America, as well as the fact that Africans are among the fastest-growing groups of US immigrants, African migrants' transit through Latin America has received scant attention and remains poorly understood. What are the recent trends and factors helping to drive this phenomenon? Moreover, what are some of the experiences and general challenges faced by African migrants undertaking the journey? Guided by a comprehensive review of the literature and an examination of materials collected from an assortment of sources, public open access databases, and various secondary data sources, the present paper examines African migration through Latin America to the US. Significantly, the present paper contributes to the relatively small body of work focused on this topic, helping to increase awareness of the geopolitics of the phenomenon and providing a better understanding of the movement of African extracontinental migrants. In particular, it explores the diverse set of factors underlying African migration in the region, and offers insight into the array of challenges they face on their long journey through Latin America. Possible scenarios for the near future and a number of potential areas for further study are also discussed.
\end{abstract}




\section{Keywords}

Africa, Latin America, Migration, Refugees, Trafficking, United States of America

\section{Introduction}

Throughout the history of humankind, people have migrated from one location to another. Migration has long been understood as a fundamental component of the human experience and today there are hundreds of millions of international migrants around the world (Collier, 2013; European Commission, 2017; King, 2012: p. 5). For many decades, one of the most heavily traveled migratory routes in the world has been the one from Latin America north toward the United States (US). Millions of people from Mexico, the Northern Triangle region of Central America (composed of the countries of El Salvador, Guatemala, and Honduras), and other parts of Latin America have traveled north in search of economic opportunity, to reunify with family members, to seek refuge from violence, insecurity, and persecution, or for various other reasons (Andreas, 2000; Massey, 2011; Massey \& Pren, 2012; Tienda \& Sanchez, 2013; Vega, 2019).

However, in recent times, particularly during the last decade, the demographic profile of migrants moving through Latin America toward the US has significantly changed and diversified. A growing number of migrants originating from countries in Africa have traveled to Latin America seeking to transit northward to the US. Despite the recent growing number of arrivals in Latin America, as well as the fact that Africans are among the fastest-growing groups of US immigrants, African migrants' transit through Latin America has received scant attention and remains poorly understood. What are the recent trends and factors helping to drive this phenomenon? Moreover, what are some of the experiences and general challenges faced by African migrants who undertake the journey? Accordingly, the present paper, informed and guided by a comprehensive review of the general literature, as well as an examination of a diverse array of materials collected from numerous sources, explores the movement of African migrants through Latin America to the US.

Notably, since most research on migration within Latin America has focused on the movement of local populations, while the majority of research conducted on African migrants has concentrated on their migration to Europe or across the continent (Capps, McCabe, \& Fix, 2012; de Haas, 2006; Hatton \& Williamson, 2003), the present paper is a useful and timely contribution to the relatively small body of work on this increasingly significant issue. Moreover, in addition to helping strengthen understanding of the geopolitics of the phenomenon, the present paper raises vital awareness of the movement of African extracontinental migrants ${ }^{1}$ and offers insight into the array of challenges that they encounter on

'The term "extracontinental" migration' is widely used throughout the region and within the literature to refer to migrants from Africa, Asia, and the Middle East (Winters \& Izaguirre, 2019). 
their long journey through Latin America.

The structure of the paper is as follows. In the next section, the methods are outlined. Subsequently, recent trends and the challenges encountered by African migrants in Latin America are reviewed. This is followed by a broad overview of the general underlying factors that drive African migration. The final section of the paper sketches a number of possible scenarios for the foreseeable future, as well as proposes several areas for further study.

\section{Methods}

The current paper is guided by a comprehensive review of the general literature and an examination of materials collected from an assortment of sources (e.g., regional or global institutions, non-governmental organizations, government agencies, etc.), public open access databases, and various secondary data sources, such as the US Border Patrol, US Department of Homeland Security, and International Organization for Migration (Boslaugh, 2007; Vartanian, 2011). Documents and materials examined include books, general reports and reviews, websites, newsletters, press releases or statements, government publications, and countless articles available from electronic academic databases (e.g., Lexis-Nexis, JSTOR, etc.) or general online searches (in order to ensure breadth and include relevant information, resources, and knowledge not always indexed in academic databases).

The information gleaned was collated, synthesized, and analyzed, with a particular emphasis and focus on enhancing general understanding of the broad trends, key themes, and different challenges associated with African migration through Latin America to the US, determining some of the significant underlying factors potentially contributing to the phenomenon, and identifying important areas or refining questions for further exploration and deeper analysis.

\section{Recent Trends and Challenges Faced by African Migrants in Latin America}

\section{Recent Trends}

For many decades, millions of people from Mexico, the Northern Triangle region of Central America, and other parts of Latin America have traveled northward seeking to enter the US. This mass migration was driven by a complex array of social, economic, demographic, political, and environmental factors (Andreas, 2000; Massey, 2011; Massey \& Pren, 2012; Tienda \& Sanchez, 2013; Vega, 2019).

In recent years, however, the number of African migrants and refugees transiting through Latin America toward the US has steadily increased (See Figure 1). Although it is difficult to pinpoint the exact number of African migrants and refugees involved within this migratory flow, particularly since much migration is clandestine or irregular and many migrants are undocumented or seek to evade detection (Laczko, 2005; Laczko \& Gramegna, 2003; Sen \& Ahuja, 2009), 


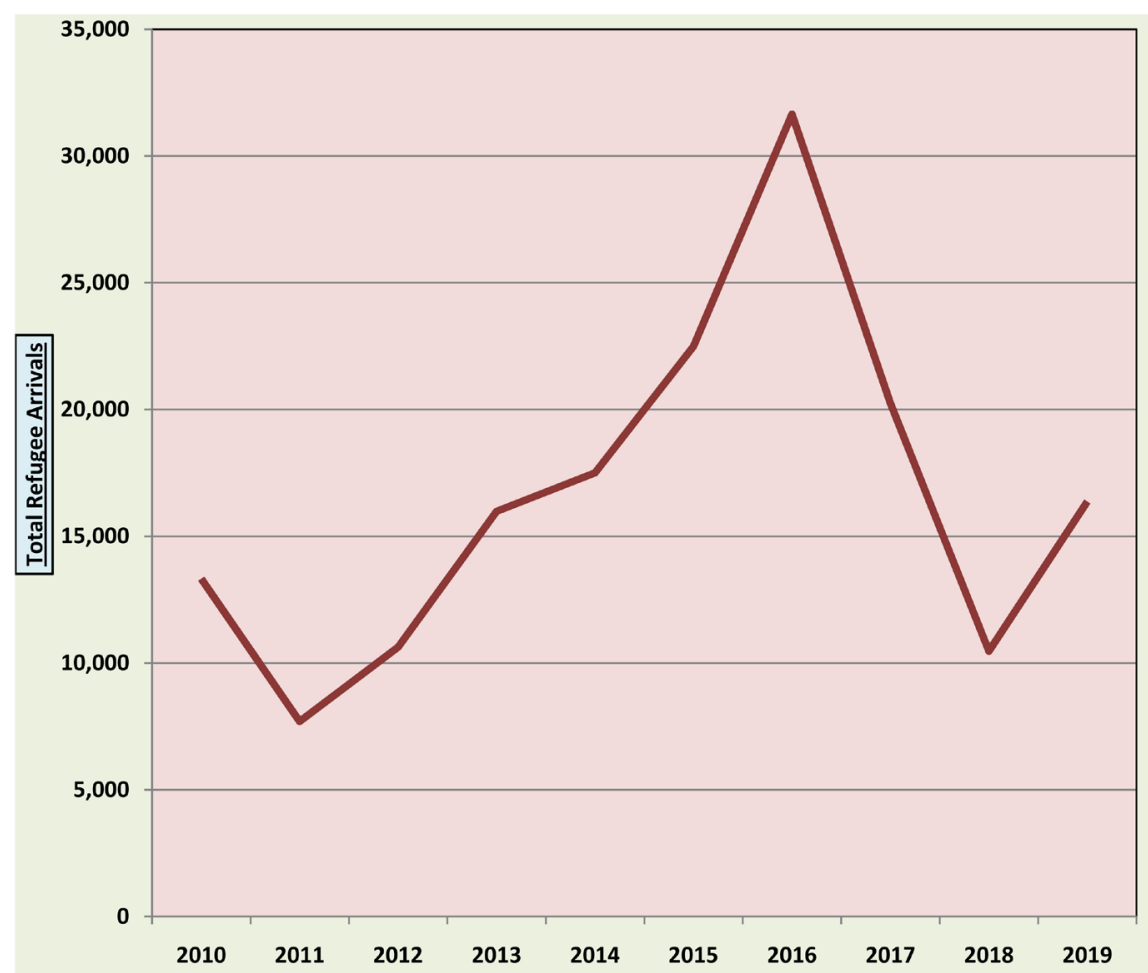

Figure 1. Annual total African refugee arrivals in the US, 2010-2019. Data are gathered from the US Department of Homeland Security (DHS, 2021).

available estimates generally illustrate an upward trajectory and it is believed that tens of thousands have made the long, arduous journey in recent years (Winters \& Izaguirre, 2019).

It is worth noting that although there has been a recent surge in African migrants and refugees transiting through Latin America toward the US, African migration remains predominantly regional, with African migrants and refugees tending to leave their own countries for elsewhere on the continent, ${ }^{2}$ or towards Europe. Moreover, the number of Africans transiting through Latin America is relatively small when compared to the overall number of Latin Americans migrating throughout the region (European Commission, 2017; IOM, 2019; UNHCR, 2019).

African migrants generally enter Latin America through legal means, typically first arriving in the Western hemisphere by flying to countries which have traditionally had lax visa requirements (e.g., Argentina, Brazil, Ecuador, or Guyana). ${ }^{3}$ Subsequently, migrants embark on long overland journeys, passing through numerous countries undocumented as they move north toward the US. Alternatively, migrants may remain in some Latin American countries for temporary periods, sometimes working within the unregulated informal economy in order to financially prepare for their onward travel to the US. The transportation methods most frequently used by African migrants include a combination of buses, ${ }^{2}$ Migrants often head to neighboring countries due to a variety of reasons, including greater awareness of opportunities, limited resources, and common cultural, ethnolinguistic, and historical roots. ${ }^{3}$ Some migrants may first enter Latin American ports by hiding on large cargo ships (Henao, 2010). 
trains, private cars, walking on foot, and small boats. African extracontinental migrants tend to come from a number of different origin countries in Africa, including Angola, Burkina Faso, Cameroon, the Democratic Republic of Congo (DRC), Ghana, Mali, Nigeria, Senegal, and countries in the Horn of Africa (USBP, 2019; Winters \& Izaguirre, 2019).

\section{Challenges}

As they travel through Latin America, African migrants face a broad array of challenges. For one, journeys can be long and strenuous, lasting months or even years, and also quite expensive. In addition, travel through the region can be highly dangerous, with African migrants having to pass through many countries that are plagued by instability, insecurity, and high levels of crime and violence.

For example, Central America is particularly dangerous; the countries of the Northern Triangle have long been blighted by some of the highest homicide rates in the world, while Mexico, the last country migrants must pass through before attempting to enter the US, has high levels of crime, corruption, and violence (Nazario, 2016; UNODC, 2014; Vogt, 2013; World Bank, 2011). A 2007 report by the United Nations Office on Drugs and Crime describes,

"The countries of Central America are diverse. But they have one thing in common. They are all affected to varying degrees by drugs, crime and poverty. Many countries of the region are vulnerable because of socio-economic conditions likeincome inequality, chaotic urbanization, mass poverty, a high proportion of youth, easy access to a large supply of guns, and an unstable post-conflict environment. They are also at risk because of their geographic position, trapped between the world's biggest suppliers and consumers of cocaine. Trafficking routes have carved paths of destruction through the region. Crime and corruption flourish while development lags"

(UNODC, 2007: p. 9).

In many areas throughout the region, armed bandits, gangs, and cartels have increasingly targeted migrants for robbery, ransom, and extortion, while migrants are also at risk of violence, abuse, and exploitation perpetrated by human smugglers and traffickers. Notably, African migrants are frequently also confronted by hostile treatment and abuse from border guards and law enforcement officials. In many countries, corrupt border guards and enforcement officials work closely with criminal gangs, solicit bribes, and fail to protect migrants from crime.

An especially dangerous leg of the journey requires African migrants to pass through the Darién Gap, which straddles southern Panama and northern Colombia (See Image 1). Considered one of the most difficult parts of the journey, the highly remote jungle region has no roads and can only be accessed by foot or small boats and canoes. The swampy jungle is filled with numerous natural risks (e.g., wild animals, poisonous insects, rough terrain, and difficult natural conditions), while drug cartels, criminal groups, and bandits also pose a danger. 


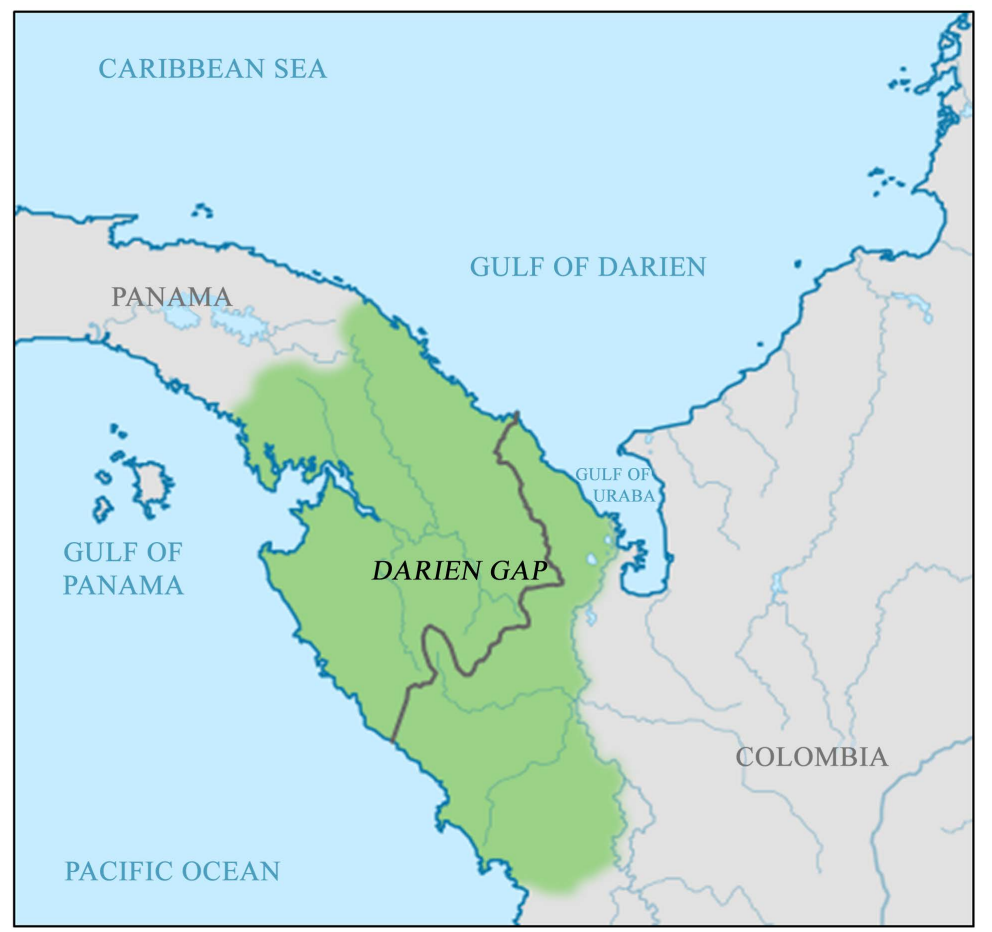

Image 1. Darién gap. Image credit:

https://commons.wikimedia.org/w/index.php?curid=66450819.

Migrants must carry all their supplies and possessions, and they face a considerable risk of exhaustion, thirst, exposure to the elements, or drowning in rivers.

In addition to contending with significant language and cultural barriers, African migrants, as visible minorities, are confronted with discrimination, racism, and xenophobia. Generally, many countries within Latin America have high levels of xenophobia and a long history of racism or antagonism toward minorities and indigenous groups (Cervone, 1999; Freier, 2013). Furthermore, as the number of African (and other) extracontinental migrants has slowly risen in many Latin American countries, raising challenges for local authorities and straining already limited state resources, there has been growing frustration, backlash, and violence from local residents.

Recently, African migrants have been confronted by a fast-changing, increasingly more challenging legal and policy framework in the region, largely led by the US government. For example, in mid-2019, Mexico began to impose restrictions on migrants, including by discontinuing the issuance of visas to African migrants allowing them to travel onward to the US. ${ }^{4}$ Mexican officials also requested African migrants to apply for residency or a visa in Mexico, something many African migrants have generally been reluctant to do. ${ }^{5}$ At Mexico's northern border with the US, a process known as "metering" significantly limited the

${ }^{4}$ These were brief 20-day tourist visas, known as "salvoconductos".

${ }^{5}$ This is for several reasons, including the fact that doing so could potentially jeopardize future asylum claims in the US, and that many Africans do not want to stay in Mexico, where they face racism, xenophobia, and discrimination, and have few viable employment opportunities. 
number of migrants accepted daily for screening, while detention facilities in the country have become severely overcrowded. These facilities, characterized by squalid, unsanitary conditions, expose migrants to violence and abuse, and they offer little access to legal or humanitarian support. The measures implemented by Mexico were in direct response to US government threats to raise trade tariffs on all products imported from Mexico until it stopped all potential migrants seeking to enter the US (Agren, 2020). ${ }^{6}$

As well, the US has completed several so-called "safe third country" agreements, which are agreements between governments stipulating that asylum seekers are required to make a claim for asylum in the country where they first arrive with countries of the Northern Triangle, seeking to return African migrants that had passed through that region, while an order from the US government made it more difficult for African migrants to claim asylum in the US. Commonly known as the "asylum ban", the order rendered ineligible for asylum any person who had passed through another country before requesting asylum in the US, raising significant challenges for African migrants and limiting their ability to take refuge in the US to seek asylum.

\section{Underlying Factors Driving African Migration}

\section{Changing Socio-Political and Security Dynamics in Europe}

The broad rise in African migration through Latin America is inextricably linked to the changing socio-political and border security dynamics in European countries. Over the past decade, Europe has experienced one of the greatest mass movements of people since World War II, with a large influx of migrants and refugees fleeing conflicts, poverty, repression, and general upheaval in parts of Africa, the Middle East, and Asia (Connor, 2016; European Commission, 2017; Eurostat, 2017; UNHCR, 2016). Many migrants and refugees have made their way to Europe over land, mainly passing through Turkey, Albania, and the Balkans, while for hundreds of thousands more, North Africa, specifically Libya, has served as a strategic launching pad to reach Europe (Amahazion, 2019; Frontex, 2018).

In 2011, NATO's military intervention in Libya led to the ouster of longtime leader Muammar Gaddafi and the government's collapse. Libya disintegrated into a failed state with an uncontrolled proliferation of weapons, lack of governance, widespread violence and corruption, and instability. Power in the country was split between several rival governments and the country was overrun by armed militias, smugglers and traffickers, various criminal networks, foreign fighters, and terrorist groups. The number of people crossing the Mediterranean Sea rapidly soared as migrants and refugees from across Africa, the Middle East, and beyond took advantage of lawlessness and a vacuum of authority to set sail

${ }^{6}$ The Mexican economy has long been highly dependent on trade with the US (Angulo, 2019; US Census Bureau, 2020), thus making the US government's threats of tariffs on Mexican goods an effective point of leverage. 
from the country's northern coast (Molenaar \& van Damme, 2017). ${ }^{7}$

The large movement of migrants and refugees into Europe has been met with increasing resistance and opposition in many countries. Many politicians and segments of the mass media have helped to stoke nationalist sentiments and encouraged racism and xenophobia against migrants and refugees. Migration has been framed as an existential "crisis" for individual nations and the broader continent, while arguments are frequently made that local norms, values, traditions, and culture could be overwhelmed and erased by migrants. Migrants are also heavily stigmatized, accused of plundering host countries, scapegoated for crimes, and blamed for local economic ills or downturns, while immigration controls are often linked to anti-terrorism. The widespread use of harsh rhetoric and labels, frequently heavily tinged with racism, not only inflames local opposition and acrimony toward migrants, it may also incite violence and aggression against them (Adekoya, 2016; Sabar \& Tsurkov, 2015; Reguly, 2018).

Politically, across Europe there has been a shift towards the far right, and many historically marginal nationalist and populist political groups have been garnering steadily growing levels of support and making unprecedented electoral gains. These far right groups are often based on a platform of racism, extreme nationalism, ethnic identity, anti-Islamization, and anti-immigration (Aisch, Pearce, \& Rousseau, 2016; BBC, 2019; Greven, 2016; Isenson, 2017; Mudde, 2017; Oxfam, 2017). ${ }^{8}$ As nationalism and populism across Europe have surged, many mainstream political parties have had to also shift sharply toward the right, thus abandoning or retreating from their core principles of tolerance and diversity.

In addition to the growth of right wing movements and a significant populist backlash, economic stagnation, austerity, and the growing strain on state resources in many countries have contributed to rising levels of public resistance, opposition, and resentment toward migrants and refugees. Within many countries, the public has strongly disapproved of how the European Union (EU) has handled the influx of migrants and refugees. Throughout Europe, but especially in so-called "frontline" states, such as Greece, Italy, and Malta, where most African refugees and migrants first arrive in the EU, providing migrants with sup${ }^{7}$ For many years, Europe partnered with Gaddafi in order to control and restrict African migration to Europe. Prior to his removal from power in 2011, Gaddafi signed agreements with Italy, then-led by Silvio Berlusconi, as well as the European Union, in which the Libyan leader agreed to toughen security measures, maritime patrols, and stem the flow of African migrants to Europe in return for financial support and Italian compensation for colonial-era crimes (Bredeloup \& Pliez, 2011; Vandvik, 2010). Before NATO's intervention in Libya, Gaddafi declared, "Now listen, you people of NATO. You're bombing a wall which stood in the way of African migration to Europe and in the way of al-Qaeda terrorists. This wall was Libya. You're breaking it" (BBC, 2018). His eventual removal from power in 2011 led to the vacuum of power and authority which contributed to the increase in migration from Libyan shores across the Mediterranean.

${ }^{8}$ Increasingly successful right-wing and anti-immigrant parties and movements in Europe include Conservative People's Party of Estonia (Estonia), Finns Party (Finland), Front National (France), Alternative for Germany (Germany), Party for Freedom (the Netherlands), Five Star Movement and Northern League (Italy), Pegida and Golden Dawn (Greece), Fidesz and Jobbik (Hungary), Sweden Democrats (Sweden), People's Party (Denmark), Vox (Spain), Law and Justice (Poland) Freedom Party(Austria), and People's Party-Our Slovakia (Slovakia). 
portive services has strained limited state resources and left countries struggling to cope (Colombo, 2013; European Commission, 2017).

Although in a large part of the EU, specifically the Schengen area, people have long moved about freely without internal border controls or security checks, ${ }^{9}$ the recent growth in migrants and refugees from Africa and the Middle East has led some countries to reintroduce temporary checks and controls at their borders with other Schengen states. ${ }^{10}$ Additionally, European countries have sought to curb the flow of migrants and refugees through increasing surveillance, tightening their policies, and implementing stronger border restrictions and security measures (European Commission, 2017; Sabar \& Tsurkov, 2015).

Europe has also heavily supported border security and migration management activities in origin countries and regions. For example, European countries have closely collaborated with governments across Africa via lucrative bilateral and multilateral agreements and international initiatives. These agreements and initiatives, worth billions of dollars, include the Khartoum Process, a dialogue and partnership between multiple European and African countries, Operation Sophia, an anti-smuggling operation by the EU's southern Mediterranean naval force, the Valletta Summit on Migration, a declaration and action plan involving 66 European and African countries, and the EU Emergency Trust Fund for Africa (Baczynska \& Körkemeier, 2016; EUEA, 2018; IOM, 2016; Khartoum Process, 2014).

Notably, in June 2018, the EU implemented a new disembarkation policy, under which Libya became the processing hub for African migrants, refugees, and asylum seekers. The EU also funded the Libyan Coast Guard to stop Africans from crossing the Mediterranean. In Libya, migrants are often held in detention centers, where they experience inhumane conditions, including severe overcrowding, unsanitary conditions, lack of access to adequate food, water, or healthcare, and extreme violence and abuse (AFP, 2017; EUEA, 2018). ${ }^{11}$

Overall, as the European socio-political landscape has drifted right, and with border controls and security measures having significantly expanded, migrating from Africa to Europe has become increasingly more difficult and highly dangerous. As a result, many African migrants and refugees have been forced to look further abroad, particularly across the Atlantic, in search of safety, security, and a better life.

Latin America is regarded as an alternative option for African migrants and refugees for a number of reasons. These include the region's relatively porous, weakly policed borders and generally open migration policies and lax visa re-

\footnotetext{
${ }^{9}$ Signed in the town of Schengen, Luxembourg in 1985, and coming into effect in 1995, the Schengen Agreement abolished many of the EU's internal borders, enabling passport-free movement across most of the bloc.

${ }^{10}$ For example, border controls between Germany and Austria, and Austria and Slovenia, were introduced in 2017.

${ }^{11}$ In July 2019, dozens of migrants and refugees at the Tajoura detention center in Libya were killed in an airstrike, an act which Michelle Bachelet, the UN High Commissioner for Human Rights, said could "amount to a war crime" (OHCHR, 2019).
} 
quirements, as well as the fact that Latin American governments often lack deportation agreements with African countries (Winters \& Izaguirre, 2019: p. 8; Vammen, 2017: p. 40). For instance, when Ecuador's new constitution was approved in 2008, it was widely regarded as "progressively transnational". It included an "open door" policy for foreigners traveling to the country and recognized the right to migrate and the free movement of all inhabitants of the planet. In addition, the government lifted all visa requirements for tourists and visitors (Freier, 2013; Ramírez, 2015). As a result of these initiatives, the country became a highly attractive destination for extracontinental migrants that wanted to move onward to the US.

\section{Structural Factors Across the African Continent}

Although the recent rise in African migration through Latin America is linked to the changing socio-political and security dynamics in Europe, African migration is rooted in a number of complex structural factors, including economics, conflict, persecution, and political concerns, environmental issues, among others. Notably, many of these are closely interrelated, with migration often being the result of a combination of factors.

One important factor driving African migration is economic. Despite recent economic growth, significant reductions in poverty, and considerable development gains in many countries throughout the continent, Africa remains the world's poorest continent, maintains a small share in global production, manufacturing, and trade, and has hundreds of millions of people living in poverty (Castaneda et al., 2018; Radelet, 2015; World Bank, 2021a; World Bank, 2021b; World Bank, 2021c; See Figure 2). Moreover, unemployment persists, levels of inequality remain high (growing prosperity has not been shared equally across income groups), social welfare safety nets are weak or nonexistent, and income gaps with the industrialized world are sizeable (World Bank, 2021d). As a result, many Africans are driven to leave their homes in search of better employment opportunities and higher wages abroad.

African migration is also driven by deadly ethnic, religious, and political conflicts, terrorism and extremism, insecurity, and instability. Furthermore, many African states are weak and extremely fragile, undemocratic, and lack key institutions, such as the rule of law, effective property rights, or an independent judiciary. Governments maintain limited levels of trust or legitimacy among the general population, and state authority and control often do not extend to all areas within their territorial jurisdictions, leading to breakdowns in law and order. Thus, Africans are forced to migrate in search of peace, security, and stability (Bowd \& Chikwanha, 2010; FSI, 2020; IDMC, 2019; UNHCR, 2020; WGI, 2019).

For example, in Cameroon, from which many African migrants in Latin America originate, there have long been tensions and deadly violence between different groups across the country, prompting thousands to flee. In Nigeria, years of conflict and extremism, including violent communal clashes and a campaign of kidnappings and attacks waged by the Islamist terror group Boko Haram, have resulted in the death, injury, and displacement of thousands, while 


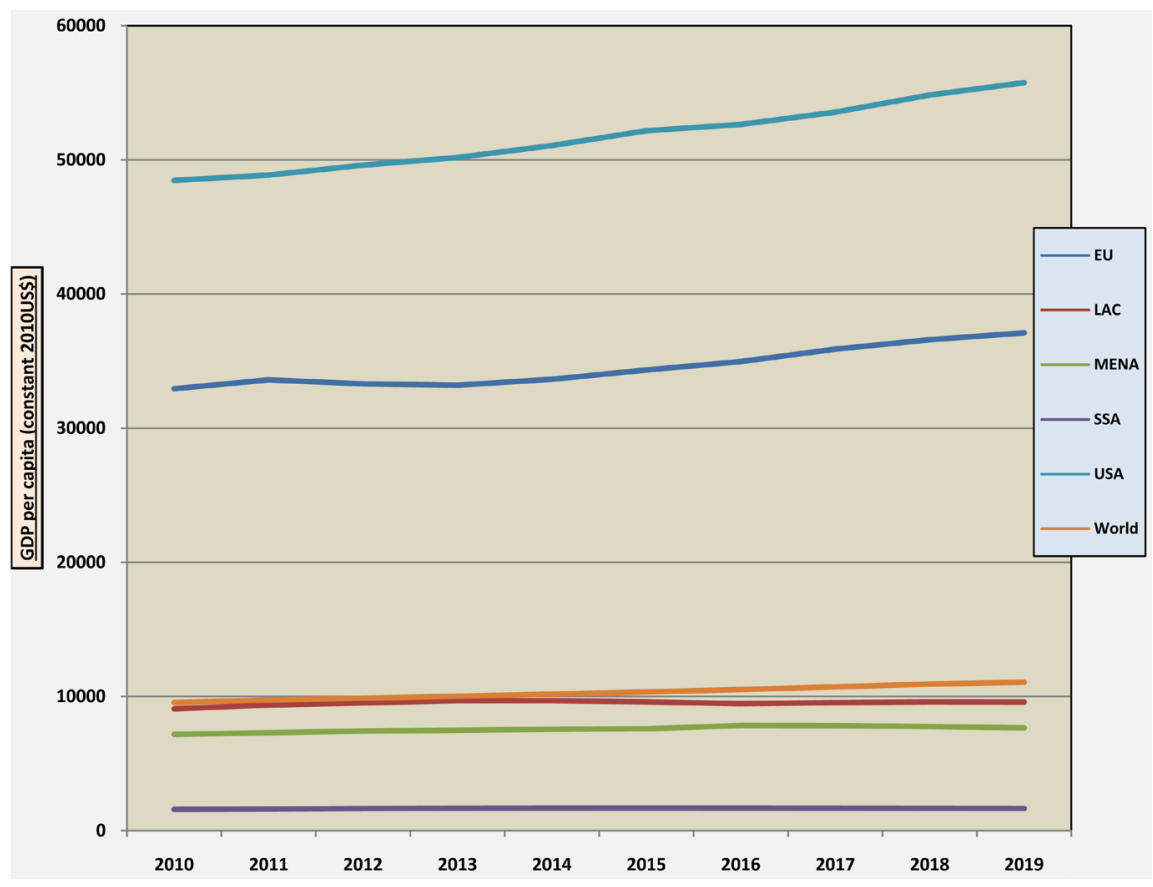

Figure 2. Regional and global GDP per capita, 2010-2019. Note: EU, European Union; LAC, Latin America and Caribbean; MENA, Middle East and North Africa; SSA, Sub-Saharan Africa; USA, United States of America. Gross domestic product (GDP) is used as a proxy measure for economic productivity, output, and wellbeing. GDP per capita is a country's GDP divided by its total population. The data are presented in 2010 constant US dollars and are gathered from the World Bank (2021c).

the Horn of Africa is one of the most conflict-affected parts of the world, long plagued by inter- and intra-state wars, terrorism, and extremism (Campbell, 2014; Kessels, Durner, \& Schwartz, 2016; Thurston, 2016). Political unrest, conflict, and extremism have also beset Mali and the DRC.

There is a growing body of literature showing that corruption, which is pervasive in many African countries (TI, 2020), is a major driver of migration, that increased corruption correlates directly with an increase in the levels of emigration from a country, and that corruption is an important facilitator of the migration process (Carling, Paasche, \& Siegel, 2015; Cooray \& Schneider, 2014; Dimant, Krieger, \& Redlin, 2015; OECD, 2015; Poprawe, 2015). What is more, corruption has a negative impact on economic opportunities, growth, stability, and security, which are all drivers of migration, suggesting it is also an indirect driver of migration (Dimant, Krieger, \& Meierrieks, 2013; Mungiu-Pippidi, 2015).

Environmental factors are also increasingly significant drivers of contemporary migration within and from Africa. Millions of poor Africans are unprotected and extremely vulnerable to climate shocks and severe weather events, while governments across the continent have limited capacity to cope, mitigate, or adapt. For the large majority of African countries, the agricultural sector remains the core of the economy, employing a large majority of the population and accounting for a significant proportion of gross domestic product. However, changing and erratic weather patterns (e.g. irregular rainfall), degradation, and 
desertification are increasing scarcity of fresh water, destroying crops and contributing to food insecurity, and devastating livelihoods across the region. In Sudan, for example, droughts have reduced sources of water for consumption and traditional agriculture, leaving many people without sufficient access to food or water. ${ }^{12}$ As well, high fertility rates and rapid urbanization across the continent are exerting tremendous pressure on freshwater, food, and other resources. ${ }^{13}$

Another important driving factor is that migration is frequently self-reinforcing. When migrants leave origin countries they share their experiences, increase awareness of opportunities, and provide various forms of assistance to those who remain behind through social networks or other means (Collier, 2013; Tall, 2004). In other cases, Africans migrate in order to reunite with spouses or other family members who have already emigrated and settled abroad.

Many Africans also migrate in search of protection and safety. For example, among those seeking asylum abroad are LGBTQI people fearing violence or abuse and political or rights activists fleeing persecution (e.g., the DRC or Cameroon). ${ }^{14}$

\section{Moving Forward and Areas for Future Study}

\section{Moving Forward}

Notwithstanding the evolving and increasingly restrictive policy framework, the growing surveillance and security measures in the region, and the recent global restrictions related to the coronavirus disease pandemic, the movement of African extracontinental migrants to and through Latin America will likely continue for the near, foreseeable future. This is down to several reasons.

For one, with long popular destinations in Europe becoming increasingly restrictive and highly difficult or dangerous to enter, African migrants will continue to search for alternative destinations, such as Latin America.

Moreover, many of the responses and measures taken to manage and control migration in Africa in recent times have failed to address the underlying, structural factors driving emigration, such as conflict, repression, and persecution, meaning that large migration flows inevitably continue. For example, Europe's partnerships with and extensive support and financial assistance to a number of African countries (e.g., Libya and Sudan), ostensibly aiming to reduce migration and combat smuggling, both embolden and confer legitimacy on the oppressive governments and abusive authorities in countries from which many migrants and refugees flee. These partnerships and financial support crucially also overlook the basic fact that many of the recipient states are highly corrupt and resis-

\footnotetext{
${ }^{12}$ Land and resource pressures, impacted by environmental factors, can also increase the possibility of disputes and conflicts.

${ }^{13}$ Although Africa is the least urbanized continent in the world, its urbanization rates are still amongst the highest in the world (World Bank, 2021e).

${ }^{14}$ Homosexual acts are a harshly punished criminal offense in a large majority of African countries, while LGTBQI+ populations face widespread intolerance, discrimination, harassment, and violence from highly traditional, religious, and conservative societies (Ottosson, 2009).
} 
tant to reform. In Sudan, which has received millions from the EU to address migration from the region, the Rapid Support Forces (RSF), a Sudanese government-backed paramilitary force with a history of brutality and violence, were utilized by the recently deposed regime of Omar al-Bashir to combat illegal migration. The RSF often utilize harsh measures against migrants, including violence and violations of human rights (EUEA, 2017; HRW, 2015; Khartoum Process, 2014).

Socio-economic and demographic trends are also likely to result in a continuation of emigration from Africa. Although slightly counterintuitive, the considerable economic growth and development recently experienced in many African countries may actually serve to drive continued emigration. First, migration involves significant risks, costs, and capabilities, which can be met with increased incomes, improved infrastructure, and cheaper transport. In addition, rising incomes, higher levels of education and literacy, and greater access to media or technology can expand people's awareness of opportunities abroad, raise material and immaterial life goals, and greatly increase aspirations to migrate (de Haas, 2010; Kritz, 2015; Massey et al., 2010; Schaub, 2012; Williams, 2009; Zelinsky, 1971).

Additionally, many countries across the continent have high fertility rates and young, growing populations, with working age populations set to increase in the near future (see Figure 3). However, domestic economic growth and job creation levels may not be strong enough to absorb all of the new entrants into the labor force. Moreover, increased urbanization, growing mechanization, and technological improvements are likely to reduce the potential for agricultural employment, raising demand for jobs. Even if Africa maintains rapid growth, income gaps and wage differentials with industrialized countries may remain large, or potentially even widen, thus constituting a powerful incentive to migrate for the foreseeable future (Collier, 2013; Skeldon, 1997; World Bank, 2021f). ${ }^{15}$

Importantly, as restrictions, security, and surveillance are increased throughout many Latin American countries, and especially at the US-Mexican border, more African migrants may choose to remain and settle in different parts of Latin America. This could lead to increased challenges for local governments, which possess limited capacity or resources, and raise significant questions regarding integration and societal adjustment for both migrants and host countries. Increased numbers of African migrants in Latin America could also contribute to a rise in conservative, exclusionary rhetoric and local politicians instrumentalizing the issue to rally support (e.g., utilizing extracontinental migrants as scapegoats for social problems or constructing migration as a crisis or threat to national security). It could also prompt states to consider the establishment of restrictive or exclusivist nationalist policies to deter extracontinental

\footnotetext{
${ }^{15}$ As well, within developing countries, including those in Africa, manufacturing industries, no longer have the capacity to absorb substantial amounts of unskilled labor from the countryside or informal activities as they once did (Rodrik, 2016).
} 


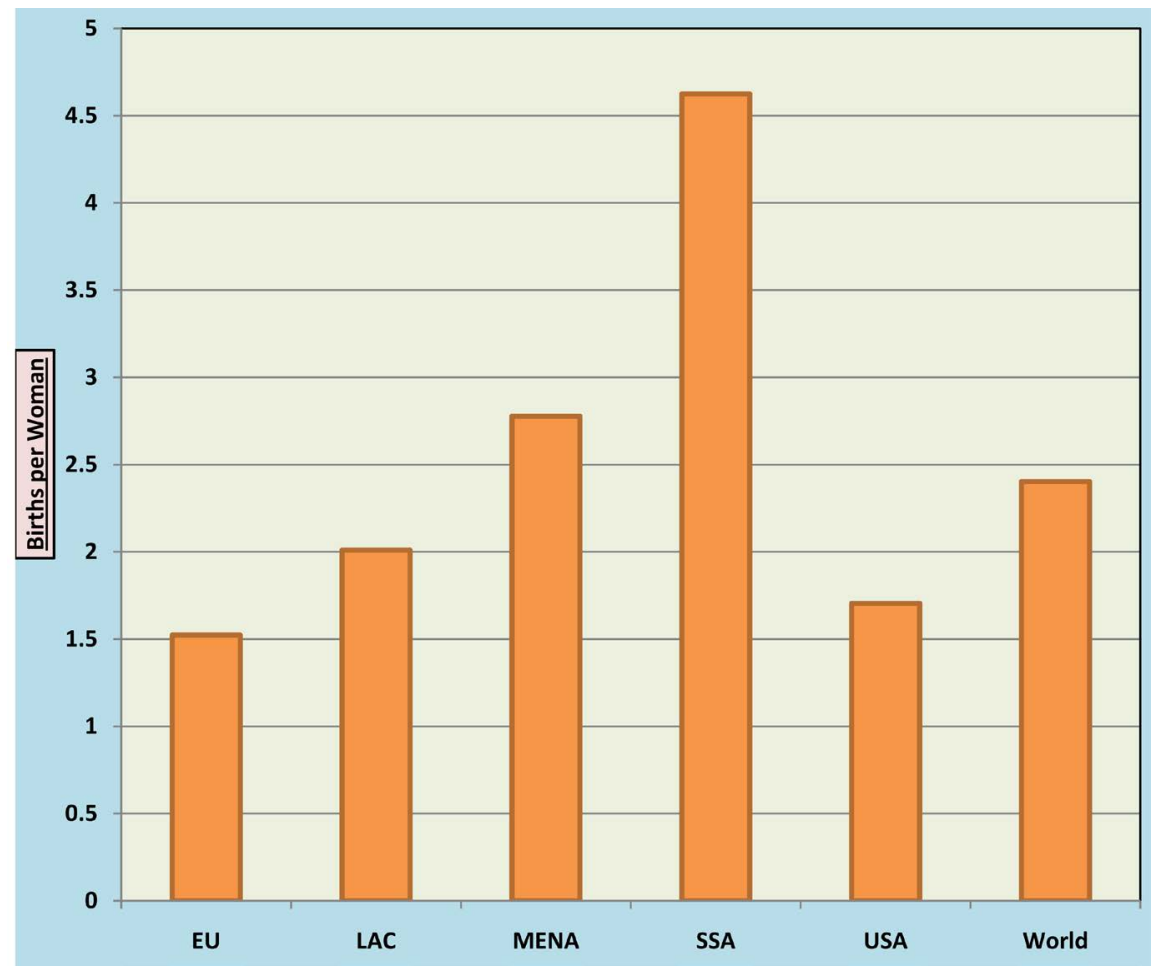

Figure 3. Regional and global fertility rates, 2019. Note: EU: European Union; LAC: Latin America and Caribbean; MENA: Middle East and North Africa; SSA: Sub-Saharan Africa; USA: United States of America. Total fertility rate represents the number of children that would be born to a woman if she were to live to the end of her childbearing years and bear children in accordance with age-specific fertility rates of the specified year (World Bank, 2021e). Although declining, the average fertility rate in Sub-Saharan Africa is the highest of any region in the world. Data are gathered from World Bank (2021e).

migration. For example, although Ecuador became a highly attractive destination for extracontinental migrants that wanted to transit onward to other countries, after several years it changed its visa requirement policies for many countries and tightened restrictions (Freier, 2013).

As African migrants increasingly move to Latin America and settle, it possibly will lead to more extracontinental arrivals in the future, since the presence of an established migrant community in a host country is a key determinant of migration flows. The costs of migration are greatly eased by the presence in the host country of a community from the country of origin. Diaspora communities and established networks can help to fuel and increase migration from the origin country in several ways, including via providing financial support, or through sharing experiences, knowledge, and personal connections or social networks that are needed to migrate (Beine, Docquier, \& Ozden, 2011; Carrington, Detragiache, \& Vishwanath, 1996; Collier, 2013).

While remaining and settling in Latin America is one possibility, another is that as migration policies are tightened, surveillance is increased, and enforcement is strengthened, African extracontinental migrants seeking to enter the US may be forced to find alternative, more dangerous routes or pushed to turn to 
human smugglers and traffickers. A large body of work from numerous settings around the world has shown how increased focus on security and surveillance to reduce migration is often ineffective, leads migrants toward more hazardous routes, forces migration further underground, and can increase human smuggling and trafficking (Anderson \& Andrijasevic, 2008; Cornelius \& Salehyan, 2007; Lepp 2002; Massey, Durand, \& Pren, 2016). ${ }^{16}$

\section{Areas for Future Study}

As a recent, growing, and rapidly evolving phenomenon, the movement of African extracontinental migrants through Latin America merits greater attention and further investigation. There are several important topics for future study. For instance, with African extracontinental migrants hitherto invisible and largely excluded in debates or conversations about migration, ethnographic or micro-level analyses can explore in-depth their perceptions, experiences, and outcomes. Additionally, longitudinal studies of extracontinental migrants can provide a dynamic picture of the experiences of these migrants over time.

When migrants move, they leave one society and become a part of another. Accordingly, future work can interrogate the various ways that extracontinental migrants impact their new host societies. For example, what are the consequences or implications of increased extracontinental migration for social cohesion, unity, solidarity, trust, and identity in host societies in Latin America?

Alternatively, work may also consider how the emigration of African extracontinental migrants impacts the political economy of their countries of origin or examine the particular ways in which extracontinental migrants influence relationships between origin and receiving countries (e.g., bilateral trade and investment flows).

\section{Funding Statement}

There are no sources of funding to declare.

\section{Human Participant Protection}

No protocol approval was required because no research involving human participants was conducted.

\section{Conflicts of Interest}

There are no conflicts of interest to declare.

\section{References}

Amahazion, F. (2019). Chapter 14. Short-Sighted Solutions: An Examination of Europe's Response to the Mediterranean Migration Crisis. In V. Fynn-Bruey, \& S. Bender (Eds.), Deadly Voyages: Migrant Journeys across the Mediterranean (pp. 235-257). Lexington Press.

Anderson, B., \& Andrijasevic, R. (2008). Sex, Slaves and Citizens: The Politics of An${ }^{16}$ Notably, human smugglers and traffickers are often highly flexible and sophisticated, and the closure of a smuggling or trafficking route generally leads to the establishment of alternative routes. 
ti-trafficking. Soundings, 40, 135-145. https://doi.org/10.3898/136266208820465065

Andreas, P. (2000). Border Games: Policing the U.S.-Mexico Divide. Cornell University Press.

Beine, M., Docquier, F., \& Ozden, C. (2011). Diasporas. Journal of Development Economics, 95, 30-41. https://doi.org/10.1016/j.jdeveco.2009.11.004

Boslaugh, S. (2007). Secondary Data Sources for Public Health-A Practical Guide. Cambridge University Press. https://doi.org/10.1017/CBO9780511618802

Bowd, R., \& Chikwanha, A. B. (2010). Understanding Africa's Contemporary Conflicts: Origins, Challenges and Peacebuilding. Institute for Security Studies.

Bredeloup, S., \& Pliez, O. (2011). The Libyan Migration Corridor. European University Institute.

Campbell, J. (2014). Boko Haram: Origins, Challenges and Responses. The Norwegian Peacebuilding Resource Center.

Capps, R., McCabe, K., \& Fix, M. (2012). Diverse Streams: Black African Migration to the United States. Migration Policy Institute.

Carling, J., Paasche, E., \& Siegel, M. (2015). Finding Connections: The Nexus between Migration and Corruption. Migration Policy Institute.

Carrington, W. J., Detragiache, E., \& Vishwanath, T. (1996). Migration with Endogenous Moving Costs. American Economic Review, 86, 909-930.

Castaneda, R. A., Doan, D. D. T., Newhouse, D. L., Nguyen, M. C., Uematsu, H., \& Azevedo, J. P. W. D. (2018). A New Profile of the Global Poor. World Development, 101, 250-267. https://doi.org/10.1016/j.worlddev.2017.08.002

Cervone, E. (1999). Racismo y vida cotidiana: Las tácticas de la defensa étnica. In E. Cervone, \& F. Rivera (Eds.), Ecuador racista: Imágenes e identidades (pp. 137-156). Facultad Latinoamericana de Ciencias Sociales.

Collier, P. (2013). Exodus: How Migration Is Changing Our World. Oxford University Press.

Colombo, M. (2013). Discourse and Politics of Migration in Italy: The Production and Reproduction of Ethnic Dominance and Exclusion. Journal of Language and Politics, 12, 157-179. https://doi.org/10.1075/jlp.12.2.01 col

Cooray, A., \& Schneider, F. (2014). Does Corruption Promote Emigration? An Empirical Examination (pp. 1-32). Discussion Paper Series Paper No. 8094, The Institute for the Study of Labor.

Cornelius, W. A., \& Salehyan, I. (2007). Does Border Enforcement Deter Unauthorized Immigration? The Case of Mexican Migration to the United States of America. Regulation \& Governance, 1, 139-153. https://doi.org/10.1111/j.1748-5991.2007.00007.x

de Haas, H. (2006). North African Migration Systems: Evolution, Transformations and Development Linkages. Migración y Desarrollo, 2, 65-95.

https://doi.org/10.35533/myd.0407.hh

de Haas, H. (2010). Migration Transitions: A Theoretical and Empirical Inquiry into the Developmental Drivers of International Migration (pp. 1-33). IMI/DEMIG Working Paper No. 24, International Migration Institute, University of Oxford.

DHS (2021). Refugees and Asylees, 2019. Office of Immigration Statistics, US Department of Homeland Security. https://www.dhs.gov/immigration-statistics/refugees-asylees

Dimant, E., Krieger, T., \& Meierrieks, D. (2013). The Effect of Corruption on Migration, 1985-2000. Applied Economics Letters, 20, 1270-1274.

https://doi.org/10.1080/13504851.2013.806776 
Dimant, E., Krieger, T., \& Redlin, M. (2015). A Crook Is a Crook ...But Is He Still a Crook Abroad? On the Effect of Immigration on Destination-Country Corruption. German Economic Review, 16, 464-489. https://doi.org/10.1111/geer.12064

EUEA (2017). EU Actions on Migration in Sudan. European Union External Action. https://eeas.europa.eu/headquarters/headquarters-homepage/34103/eu-actions-migrati on-sudan en

EUEA (2018). EU-Libya Relations. European Union External Action. https://eeas.europa.eu/headquarters/headquarters-homepage en/19163/EU-Libya\%20r elations

European Commission (2017). What Is the Migration Crisis? What the EU Is Doing? European Commission.

https://op.europa.eu/en/publication-detail/-/publication/e9465e4f-b2e4-11e7-837e-01a $\underline{\text { a75ed71a1 }}$

Eurostat (2017). Asylum Applications (Non-EU) in the EU-28 Member States, 2006-2016. Eurostat.

http://appsso.eurostat.ec.europa.eu/nui/show.do?query=BOOKMARK DS-054424 QI D -DAA58D8 UID -3F171EB0\&layout=TIME,C,X,0;GEO,L,Y,0;CITIZEN,L,Z,0;UNI T,L,Z,1;INDICATORS,C,Z,2;\&zSelection=DS-054424CITIZEN,TOTAL;DS-054424UN IT,PER;DS-054424INDICATORS,OBS FLAG;\&rankName1=UNIT 1 1 2 -

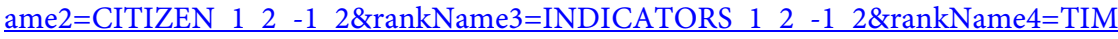

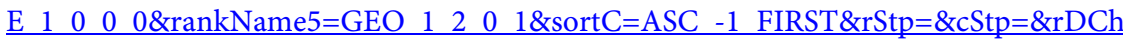
$=\& \mathrm{cDCh}=\& \mathrm{rDM}=$ true $\& \mathrm{cDM}=$ true $\&$ footnes=false $\&$ empty=false \&wai=false $\&$ time $\mathrm{mod}$ e=ROLLING\&time most recent=true\&lang=EN\&cfo=\%23\%23\%23\%2C $\% 23 \% 23 \% 23$. \%23\%23\%23

Freier, L. F. (2013). Open Doors (for Almost All): Visa Policies and Ethnic Selectivity in Ecuador (pp. 1-24). Working Paper 188, London School of Economics, Center for Comparative Immigration Studies.

Frontex (2018). Risk Analysis for 2018. Frontex.

FSI (2020). The Fragile States Index: 2020. Fund for Peace. https://fragilestatesindex.org/

Greven, T. (2016). The Rise of Right-Wing Populism in Europe and the United States: A Comparative Perspective. Friedrich Ebert Foundation.

Hatton, T. J., \& Williamson, J. G. (2003). Demographic and Economic Pressure on Emigration Out of Africa. Scandinavian Journal of Economics, 105, 465-486. https://doi.org/10.1111/1467-9442.t01-2-00008

HRW (2015). Men with No Mercy": Rapid Support Forces Attacks against Civilians in Darfur, Sudan. Human Rights Watch.

IDMC (2019). Internal Displacement Monitoring Center: Africa Report on Internal Displacement. Internal Displacement Monitoring Center.

IOM (2016). IOM-EU Cooperation on Migration and Mobility: Addressing the Valletta Summit Priorities Together. The International Organization for Migration.

IOM (2019). World Migration Report: 2020. International Organization for Migration.

Kessels, E., Durner, T., \& Schwartz, M. (2016). Violent Extremism and Instability in the Greater Horn of Africa: An Examination of Drivers and Responses. Global Center on Cooperative Security.

Khartoum Process (2014). EU-Horn of Africa Migration Route Initiative. https://www.khartoumprocess.net

King, R. (2012). Theories and Typologies of Migration: An Overview and a Primer. In E. Righard (Ed.), Willy Brandt Series of Working Papers in International Migration and 
Ethnic Relations 3/12 (pp. 1-48). Malmö Institute for Studies of Migration, Diversity and Welfare.

Kritz, M. M. (2015). International Student Mobility and Tertiary Education Capacity in Africa. International Migration, 53, 29-49. https://doi.org/10.1111/imig.12053

Laczko, F. (2005). Data and Research on Human Trafficking. International Migration, 43, 5-16. https://doi.org/10.1111/j.0020-7985.2005.00309.x

Laczko, F., \& Gramegna, M. A. (2003). Developing Better Indicators of Human Trafficking. Brown Journal of World Affairs, 10, 179-194.

Lepp, A. (2002). Trafficking in Women and the Feminization of Migration. Canadian Woman Studies/Les Cahiers de la Femme, 21/22, 90-99.

Massey, D. S. (2011). The Past and Future of Mexico-U.S. Migration. In M. Overmyer-Velázquez (Ed.). Beyond la Frontera: The History of Mexico-US Migration (pp. 241-265). Oxford University Press.

Massey, D. S., \& Pren, K. A. (2012). Unintended Consequences of US Immigration Policy: Explaining the Post-1965 Surge from Latin America. Population and Development Review, 38, 1-29. https://doi.org/10.1111/j.1728-4457.2012.00470.x

Massey, D. S., Durand, J., \& Pren, K. A. (2016). Why Border Enforcement Backfired. American Journal of Sociology, 121, 1557-1600. https://doi.org/10.1086/684200

Massey, D. S., Williams, N., Axinn, W. G., \& Ghimire, D. J. (2010). Community Services and Out-Migration. International Migration, 48, 1-41.

https://doi.org/10.1111/j.1468-2435.2009.00581.x

Molenaar, F., \& van Damme, T. (2017). Irregular Migration and Human Smuggling Networks in Mali. The Clingendael Institute.

Mungiu-Pippidi, A. (2015). The Quest for Good Governance; How Societies Develop Control of Corruption. Cambridge University Press. https://doi.org/10.1017/CBO9781316286937

OECD (2015). Responses to the Refugee Crisis: Corruption and the Smuggling of Refugees. Organization of Economic Cooperation and Development.

OHCHR (2019). Statement by UN High Commissioner for Human Rights Michelle Bachelet. The Office of the High Commissioner for Human Rights.

https://www.ohchr.org/EN/NewsEvents/Pages/DisplayNews.aspx?NewsID=24784\&Lan $\mathrm{gID}=\mathrm{E}$

Ottosson, D. (2009). State-Sponsored Homophobia. International Lesbian, Gay, Bisexual, Trans, and Intersex Association.

Poprawe, M. (2015). On the Relationship between Corruption and Migration: Empirical Evidence from a Gravity Model of Migration. Public Choice, 163, 337-354. https://doi.org/10.1007/s11127-015-0255-x

Radelet, S. (2015). The Great Surge: The Ascent of the Developing World. Simon and Schuster.

Ramírez G., J. P. (2015). Migration Policy in the New Ecuadorean Constitution: Toward the Formation of a Transnational Nation-State. Latin American Perspectives, 43, 175-186. https://doi.org/10.1177/0094582X15586563

Rodrik, D. (2016). Is Liberal Democracy Feasible in Developing Countries? Studies in Comparative International Development, 51, 50-59. https://doi.org/10.1007/s12116-016-9218-6

Sabar, G., \& Tsurkov, E. (2015). Israel's Policies toward Asylum-Seekers: 2002-2014. Instituto Affari Internazionali Working Papers Series, 15, 1-18. 
Schaub, M. L. (2012). Lines across the Desert: Mobile Phone Use and Mobility in the Context of Trans-Saharan Migration. Information Technology for Development, 18, 126-144. https://doi.org/10.1080/02681102.2011.604082

Sen, S., \& Ahuja, J. (2009). Trafficking in Women and Children: Myths and Realities. Concept Publishing Company.

Skeldon, R. (1997). Migration and Development: A Global Perspective. Longman.

Tall, S. M. (2004). Senegalese Émigrés: New Information and Communication Technologies. Review of African Political Economy, 31, 31-48. https://doi.org/10.1080/0305624042000258405

Thurston, A. (2016). The Disease Is Unbelief": Boko Haram's Religious and Political Worldview. The Brookings Institution. https://doi.org/10.2307/j.ctvc779gc

TI (2020). Transparency International: Corruption Perceptions Index. Transparency International. https://www.transparency.org/

Tienda, M., \& Sanchez, S. (2013). Latin American Immigration to the United States. Daedalus, 142, 48-64. https://doi.org/10.1162/DAED a 00218

UNHCR (2016). UNHCR Global Trends: Forced Displacement in 2016. United Nations High Commissioner for Refugees. http://www.unhcr.org/globaltrends2016/

UNHCR (2020). The United Nations High Commissioner for Refugees (UNHCR): Figures at a Glance. United Nations High Commissioner for Refugees.

https://www.unhcr.org/data.html

UNODC (2007). Crime and Development in Central America: Caught in the Crossfire. Vienna: United Nations Office on Drugs and Crime.

UNODC (2014). International Homicide Rates. United Nations Office on Drugs and Crime.

https://www.unodc.org/gsh/en/data.html

US Census Bureau (2020). United States Trade in Goods with Mexico. United States Census Bureau. https://www.census.gov/foreign-trade/balance/c2010.html

USBP (2019). United States Border Patrol Nationwide Apprehensions by Citizenship and Sector (2007-2019). United States Border Patrol. https://www.cbp.gov/newsroom/media-resources/stats

Vammen, I. M. (2017). Sticking to God: Brokers of Hope in Senegalese Migration to Argentina. In N. Kleist, \& D. Thorsen (Eds.), Hope and Uncertainty in Contemporary African Migration (pp. 40-57). Routledge. https://doi.org/10.4324/9781315659916-3

Vartanian, T. P. (2011). Secondary Data Analysis. Oxford University Press. https://doi.org/10.1093/acprof:oso/9780195388817.001.0001

Vega, L. A. A. (2019.) López Obrador's Initial Policies Toward Central American Migrants: Implications for the U.S. Rice University, Baker Institute for Public Policy.

Vogt, W. A. (2013). Crossing Mexico: Structural Violence and the Commodification of Undocumented Central American Migrants. American Ethnologist, 40, 764-780. https://doi.org/10.1111/amet.12053

WGI (2019). The Worldwide Governance Indicators. The World Bank Group. http://www.govindicators.org

Williams, N. (2009). Education, Gender, and Migration in the Context of Social Change. Social Science Research, 38, 883-896. https://doi.org/10.1016/j.ssresearch.2009.04.005

Winters, N., \& Izaguirre, C. M. (2019). Es Cosa Suya: Entanglements of Border Externalization and African Transit Migration in Northern Costa Rica. Comparative Migration Studies, 7, Article No. 27. https://doi.org/10.1186/s40878-019-0131-9 
World Bank (2011). Crime and Violence in Central America: A Development Challenge. The World Bank Group.

World Bank (2021a). World Bank Development Indicators: Classification of Countries by Income. The World Bank Group.

http://datatopics.worldbank.org/world-development-indicators/stories/the-classificatio n-of-countries-by-income.html

World Bank (2021b). World Bank: Poverty and Equity Data Portal. The World Bank Group. http://povertydata.worldbank.org/poverty/home/

World Bank (2021c). World Bank: GDP per Capita (2010 Constant US\$). The World Bank Group. https://data.worldbank.org/indicator/NY.GDP.PCAP.KD

World Bank (2021d). World Bank: Gini Index. The World Bank Group. http://data.worldbank.org/indicator/SI.POV.GINI

World Bank (2021e). World Bank: Urban Population (\% of Total Population). The World Bank Group. https://data.worldbank.org/indicator/SP.URB.TOTL.IN.ZS

World Bank (2021f). World Bank: Fertility Rate, Total. The World Bank Group. https://data.worldbank.org/indicator/SP.DYN.TFRT.IN

Zelinsky, Z. (1971). The Hypothesis of the Mobility Transition. Geographical Review, 61, 219-249. https://doi.org/10.2307/213996

Vandvik, B. (2010, October 20). The EU's Dubious Refugee Deal. The Guardian. https://www.theguardian.com/commentisfree/2010/oct/20/eu-refugee-libya-gaddafi

Henao, L. A. (2010 November 15). African Immigrants Drift toward Latin America. Reuters. http://www.reuters.com/article/idUSTRE5AF0AG20091116

Connor, P. (2016, August 2). Number of Refugees to Europe Surges to Record 1.3 Million in 2015. Pew Research Center.

https://www.pewresearch.org/global/2016/08/02/number-of-refugees-to-europe-surges -to-record-1-3-million-in-2015/

Nazario, S. (2016, August 11). How the Most Dangerous Place on Earth Got a Little Bit Safer. New York Times.

https://www.nytimes.com/2016/08/14/opinion/sunday/how-the-most-dangerous-place -on-earth-got-a-little-bit-safer.html

Adekoya, R. (2016, October 25). Xenophobic, Authoritarian-And Generous on Welfare: How Poland's Right Rules. The Guardian.

https://www.theguardian.com/commentisfree/2016/oct/25/poland-right-law-justice-pa rty-europe

Aisch, G., Pearce, A., \& Rousseau, B. (2016, December 5). How Far Is Europe Swinging to the Right? New York Times.

https://www.nytimes.com/interactive/2016/05/22/world/europe/europe-right-wing-aus tria-hungary.html

Baczynska, G., \& Körkemeier, T. (2016, December 12). EU Agrees Money-for-Migration Deal With Mali. Reuters.

https://www.reuters.com/article/us-europe-migrants-eu-mali/eu-agrees-money-for-mi gration-deal-with-mali-idUSKBN141158

Mudde, C. (2017, September 24). What the Stunning Success of AfD Means for Germany and Europe. The Guardian.

https://www.theguardian.com/commentisfree/2017/sep/24/germany-elections-afd-euro pe-immigration-merkel-radical-right

Oxfam (2017, October 11). Oxfam: Grave Abuse Shows Urgent Need for Shift on EU Migration Agenda. Oxfam International. 
https://www.oxfam.org/en/pressroom/pressreleases/2017-10-11/oxfam-grave-abuse-sh ows-urgent-need-shift-eu-migration-agenda

Isenson, N. (2017, October 12). Freedom Party of Austria-What You Need to Know. Deutsch Welles.

http://www.dw.com/en/freedom-party-of-austria-what-you-need-to-know/a-40928152

AFP (2017, November 14). EU's Policy of Helping Libya Intercept Migrants Is 'Inhuman', Says UN. Agence France-Presse.

https://www.theguardian.com/world/2017/nov/14/eu-libya-coastguard-detention-centr es-migration-mediterranean-un-zeid-raad-al-hussein

Reguly, E. (2018, February 28). Italy Lurches to the Xenophobic Right in Election Centred on Immigration. The Globe and Mail.

https://www.theglobeandmail.com/amp/news/world/italy-lurches-to-the-xenophobic-r ight-in-election-centred-on-immigration/article38144969/

BBC (2018, July 7). How Libya Holds the Key to Solving Europe's Migration Crisis. BBC. https://www.bbc.com/news/world-africa-44709974

UNHCR (2019, April 16). One Year into Nicaragua Crisis, More than 60,000 Forced to Flee Their Country. United Nations High Commissioner for Refugees.

https://www.unhcr.org/news/briefing/2019/4/5cb58bd74/year-nicaragua-crisis-60000-f orced-flee-country.html

Angulo, S. (2019, August 1). Mexico's Dependence on U.S. Demand Spells Trouble for Weak Economy. Reuters.

https://www.reuters.com/article/us-mexico-economy-analysis/mexicos-dependence-on -us-demand-spells-trouble-for-weak-economy-idUSKCN1UR5LT

BBC (2019 November 13). Europe and Right-Wing Nationalism: A Country-by-Country Guide. $B B C$. https://www.bbc.com/news/world-europe-36130006

Agren, D. (2020, January 26). “Mexico Has Become Trump's Wall”: How Amlo Became an Immigration Enforcer. The Guardian.

https://www.theguardian.com/world/2020/jan/26/mexico-immigration-amlo-enforcem ent-trump 